\title{
'n Politieke tegnologie van die vroeë Christen se gepynigde liggaam ${ }^{1}$
}

J N Vorster

(Universiteit van Suid-Afrika)

\section{ABSTRACT}

\section{A political technology of the early Christian martyr's pained body}

The early Christian martyr is usually only seen in terms of testimony or witness. It is argued that a political technology of the body enables us to see the manner in which the pained body of the early Christian martyr functioned as a space upon which political strategies for the empowerment of interested parties were enacted.

\section{INLEIDEND}

Die pyn en lyding van menslike liggame vorm ' $n$ wesentlike deel van die Christendom se diskoers en dit het sy ontstaan reeds in die vroeë Christendom. Martelaarskap vorm nie alleen deel van hierdie diskoers nie, maar het om een of ander rede bygedra tot die antreklikheid van die vroeë Christendom. Wanneer kontemporêr aangetoon word dat martelaarskap as ' $n$ soort van ' $n$ katalisator vir die verspreiding van die Christendom gefunksioneer het, word dit meermale toegeskryf aan die waarheid van die evangelie en die gewilligheid om vir die waarheid van die evangelie te sterwe. In Derde Wêreldlande soos in Suid-Amerika en Suid-Afrika word meermale ook gepoog om 'n kontinuïteit te vestig tussen die martelaarskappe van die vroeë Christendom en die marteling wat onder onderdrukkende regimes plaasvind. 'n Effek van die rol wat martelaarskap in die geskiedenis van die Christendom gespeel het, is om dit te verheerlik - om gefolter en gedood te word vir dit waarin jy glo, word voorgestel as bewonderingswaardig (sien Balasundaram 1993; Figura 1996; Fernando 1998).

Ek wil met hierdie artikel eerstens argumenteer eerstens dat die aantreklikheid van die martelaarskappe van die vroeë Christendom nie net om die belydenis van Jesus Christus gedraai het nie, maar dat die martelaarskappe van die eerste paar eeue van die Christendom binne die raamwerk van wat Foucault noem ' $n$ politieke tegnologie van die liggaam gesien moet word. Indien die martelaarskappe van die eerste paar eeue

\footnotetext{
${ }^{1}$ Hiermee my dank aan Me Lizel Voges-Bonthuys wat met die versameling van bibliografiese materiaal behulpsaam was en aan Unisa se Navorsingsinstituut vir Teologie en Godsdienswetenskap vir haar befondsing.
} 
breër geproblematiseer word, blyk dit gou dat die populariteit van die martelare nie net aan hulle geloof of hulle belydenis toegeskryf kan word nie. Terselfdertyd verhinder so ' $n$ politieke tegnologie van die liggaam dat die liggaam uit die martelingsaktiwiteit verdwyn. Soos wat Sinoptiese Evangelie navorsing, onder die vaandel van Historiese Kritiek, maar eintlik gedrewe deur ' $n$ kanonies gemotiveerde drang vir die oorspronklike en outentieke, vir lang periodes gedomineer was deur ' $n$ soektog na die outentieke Jesus woorde, blyk die soektog na "outentisiteit", ewe eens onder die vaandel van historiese navorsing, te sentreer rondom die sogenaamde Acta of commentarii, die "notules" van die regsverrigtinge waarin dan ook die belydenis rondom Christenskap voorkom, die martelingsnavorsing te domineer'. Die invalshoek van ' $n$ politieke tegnologie van die liggaam help ons om nie net die martelaarskappe vanuit die propaganda van die vroeë Christendom te verstaan nie, maar om dit in samehang met die groeiende mag van die keiser te verstaan. Derdens wil ek aantoon dat, indien die martelaarskappe van die eerste paar eeue binne die raamwerk van ' $n$ politieke tegnologie van die liggaam geplaas word, kan daar geen kontinuilteit met die marteling van Christene in kontemporêre situasies gestel word nie. Trouens, benewens die feit dat dit nooit grootskaals was nie, was die beklemtoning daarvan polities reeds problematies toe die Christendom staatsgodsdiens geraak het.

Alvorens die martelaarskappe van die vroeë Christendom aan die orde gestel word, sal eers kortliks aangetoon word hoe martelaarskap binne die raamwerk van ' $n$ politieke tegnologie van die liggaam verstaan kan word.

\section{MARTELING AS STRAFPRAKTYK WAT DIE LIGGAAM POLITISEER}

Moontlik is daar min plekke waar die magspraktyke van 'n gemeenskap so in wrede kompetisie met mekaar uitgewoed word as in die marteling van die liggaam. Marteling vorm deel van die strafpraktyke van ' $n$ gemeenskap, maar dit onderskei dit van ander strafpraktyke in die uitsluitlike konsentrasie en toediening van pyn op die liggaam. Om die waarheid te sê, die toediening van pyn funksioneer so sentraal in marteling dat selfs die dood nie as die doel van marteling gesien kan word nie; eerder gaan dit om die uitstel van die doodsmoment sodat die periode waarin die liggaam aan pyn onderwerp word, verleng kan word. Dit is

\footnotetext{
${ }^{2}$ Sien byvoorbeeld Manson (1957:478), wat instemmend aantoon dat Delehaye die eerste was om ' $n$ onderskeid te maak tussen Acta en Passio. Waar eersgenoemde as meer "betroubaar" gereken word, word laasgenoemde as meer "grafies" en oop vir verwerkings verklaar. Hoewel Manson (1957:463-464) die vraag van "pyn" oorweeg, is sy artikel ' $n$ uitstekende voorbeeld van hoe die pyn en die liggaam verdwyn ten gunste van 'n tradisiegeskiedenis rondom martelaarsgetuienis.
} 
dan ook presies hierdie doelbewuste toediening van pyn wat marteling na die $18 \mathrm{e}$ eeu onaanvaarbaar as ' $n$ juridiese strafpraktyk gemaak het.

Foucault (1977) wys daarop dat daar ' $n$ wesentlike verandering in strafpraktyke vanaf die einde $17 \mathrm{e}$ en begin $18 \mathrm{e}$ eeu plaasgevind het. Hoewel sy voorbeelde en gegewens tot ' $n$ groot mate afkomstig is uit die post-Verligting tydperk en hoofsaaklik met Frankryk en Engeland te doen het, verskaf dit tot ' $n$ mate ' $n$ terminologie waarmee die komplekse aard van marteling verstaan en gesien kan word as ' $n$ vergestalting van ' $n$ politieke tegnologie van die liggaam.

Die marteling van die liggaam, oftewel die doelbewuste toediening van pyn, vorm deel van aanvaarde strafpraktyk tot aan die begin van die $18 \mathrm{e}$ eeu. Tot en met die 18 eeu vorm die liggaam as sodanig die terrein waarop die soewereine staat met barbaarse geweld sy gesag afdwing en wraak neem op ' $n$ aantasting van die wetskodes. Omdat strafpraktyk aan die een kant die mag van die soewerein en die onaantasbaarheid van sy kodes moes bevestig en aan die ander kant moes aantoon hoe die gemeenskap beskerm word deur die soewerein, geskied straf meestal in die teenwoordigheid van die publiek. Die openbare martelingsproses is ' $n$ politieke ritueel wat die regte van die wetsgehoorsame moet herstel en bevestig. Ten diepste is die soewerein verontreg. Foucault (1977:47) skryf: "the crime attacks the sovereign: it attacks him personally, since the law represents the will of the sovereign". So word die toediening van straf " $n$ openbare aangeleentheid - dit behoort tot die terrein van die spektakulêre en aanskoulike. Maar fundamentele elemente in die drama van die spektakulêre is die liggaain en die pyn wat die liggaam moet ondergaan. Tussen strafpraktyk wat afspeel in die publieke sfeer en ' $n$ fokus op die liggaam as ' $n$ ruimte waarop die gemeenskapsnorme met geweld geskryf word, bestaan ' $n$ onlosmaaklike verband. Nie die dood nie, maar die pyniging van die liggaam word die doel van die strafpraktyk. Om die waarheid te sê, hoe langer die liggaam aan pyn onderwerp kan word, en die doodsmoment uitgestel kan word, des te meer word die vergeldende eis van die gemeenskap bevredig. Dit sou dus goedskiks kon gebeur dat so " $n$ proses van marteling oor dae kon plaasvind wat opsigself die aanskouingswaarde verhoog. "n Hele "wetenskap" ontwikkel oor hoe die liggaam met tussenposes en met verskillende tegnieke van marteling so lank as moontlik aan die lewe gehou kan word. En die kwaliteit van die laksman bestaan in die wyse waarop suksesvol uiting gegee kan word aan die vonnis voltrekking deur volhardende toediening van pyn. Foucault beskryf die laksman as "an anatomist of pain"! (Foucalt, $1977: 11)$.

Die strafpraktyk voor die begin van die $18 \mathrm{e}$ eeu vereis nie dat daar 'n gelykwaardigheid tussen straf en misdaad bestaan nie. Daar kan ook nie ' $n$ simmetrie bestaan tussen straf en misdaad nie, omdat die persoon van die soewerein deur die oortreding angetas is en derhalwe deur die 
straf geherkonstitueer moet word. Omdat hierdie herkonstituering in die openbaar plaasvind en die aanskoulike integrale deel vorm van die strafpraktyk, word ' $n$ gelykwaardigheid verder veronagsaam. Al sou die dood nie die einde van die strafproses wees nie, moet die liggaam van die veroordeelde gemerk word as een wat dit gewaag het om teen die soewerein op te staan. Die intensiteit van die straf moes beantwoord aan die graad van aanstootlikheid wat die misdaad na vore geroep het. Dit gaan nie om die misdaadshandeling self nie, maar om die gemeenskapswaarde(s) wat geskend is. Die oormatige geweld waaraan die liggaam onderwerp word, toon aan die publiek die mag en die glorie van soewereine reg. So word die "seremonie van straf, dan, 'n oefening in 'terreur"' (Foucault 1977: 49).

Volgens Foucault (1977:8-10) is dit juis hierdie uitermatige geweld wat uiteindelik die teenoorgestelde effek gehad het. Instede daarvan dat blaam gekonsentreer was op die misdadiger, het die brutale en oormatige geweld en die seremoniële ritualiteit die drama gekonstitueer waarin die makers en toepassers van die wet ook hulle rolle gehad het. ' $n$ Ommekeer van rolle het begin posvat, wat die laksman tot ' $n$ misdadiger gemaak het, die regters tot moordenaars, en aan die oortreders simpatie en bewondering besorg het (1977:9). So word na die begin van die 18e eeu, die strafpraktyk verwyder vanuit die oog van die publiek. Met die verwydering gaan daar ook ' $n$ eliminasie van liggaamlike pyn gepaard. Dit beteken nie dat die liggaamlike ooit uit die strafpraktyk geskryf word of kan word nie, maar dit beteken wel dat daar ' $n$ graduele wegbeweeg is van die pyniging van die liggaam as doel van strafpraktyk.

Marteling, oftewel die doelbewuste toediening van pyn onder die skyn van ' $n$ uitvoering van juridies-politiese mag, kom nie tot ' $n$ einde met die begin van die $18 \mathrm{e}$ eeu nie. Strafpraktyke in Westerse maatskappye, gesanksioneer deur die gemeenskappe se juridies-politiese sisteme poog egter om die toediening van pyn te verminder, die periode te verkort en uit te skakel. Ten spyte van die feit dat die liggaamlike nie uit strafpraktyke verdwyn nie, is die oogmerk nie meer om geweldadig die liggaam vir solank as moontlik aan pyn te onderwerp nie. Dit beteken egter glad nie dat marteling tot ' $n$ einde gekom het nie. Wanneer marteling nog voorkom, gebeur dit gewoonlik uit die publieke oog en sonder die sanksionering van die algemene publiek. Om daardie rede verskaf onderdrukkende regimes ook gewoonlik nie hulle samewerking om informasie te verskaf oor die gewelddadige hantering van politieke misdadigers nie (sien byvoorbeeld Scarry 1985:329). Die punt is egter dat die voorwaardes op grond waarvan hierdie soort marteling geskied, is egter nie dieselfde as dit wat ons voor die $18 \mathrm{e}$ eeu aantref nie. Des te minder kan 'n kontinuïteit met die martelingspraktyke en ervaringe van die vroeë Christendom gepretendeer word. Waar die marteling van die lig- 
gaam deel was van amptelike strafpraktyk, en die publieke aard daarvan die politiese strategie bevestig het, word die terreine nou geskei.

Dit is egter belangrik om raak te sien dat gemeenskappe nie alleen met hierdie openbare gewelddadigheid saamgeleef het nie, maar dit ook gekondoneer en aangemoedig het. As strafpraktyk was openbare marteling, met die fokus op die doelbewuste pyniging van die liggaam, deel van aanvaarde, normatiewe praktyk. Sou daar bewyse wees dat nou en dan daarteen geprotesteer is, neem dit nie weg dat bloeddorstige gewelddadigheid gemeenskapswaardes gekonstitueer en in stand gehou het nie. Marteling was gesien as "reg". Indien marteling in 'n regskode ingeskryf kon word, beteken dit dat gewelddadigheid deel moes uitgemaak het van daardie sosiale voorkeure wat ' $n$ gemeenskap se alledaagse lewenshouding bepaal het - dit het ' $n$ norm generende rol gespeel. Sonder om vooruit te gryp, is die konsekwensie hiervan dat geweld klaarblyklik nie weerstand en weersin wek waar martelaarskap floreer, aangemoedig, en selfs verheerlik kan word nie. Vir die verstaan van die vroeg Christelike aangrype van martelaarskap is dit belangrik om die omhelsing van geweld raak te sien. Anders gestel: martelaarskap kan alleen aantreklikheid verkry waar gewelddadigheid politieke voordeel inhou.

\section{DIE GEPOLITISEERDE LIGGAAM VAN VROEG CHRIS- TELIKE MARTELARE}

Die vraag is nou hoe die liggame van die vroeg Christelike martelare die ruimte of plek geword waarop die komplekse magsrelasies van die eerste paar eeue van die Romeinse imperiale tydperk hulleself uitgewoed het. Dit sal mettertyd duidelik word dat dit nie maar net om ' $n$ "sterf vir die waarheid van die evangelie" of die dappere lewering van getuienis in die aangesig van die dood gegaan het nie, maar dat verskillende partye bloeddorstig hulle magsbelange via die liggame van die martelare wou handhaaf.

\section{1 "Om te betaal aan die Keiser wat die Keiser toekom"}

Die martelaarskap van sommige vroeë Christene gaan hand aan hand met die stadige en oneweredig verspreide toename in die status van die Keiserkultus. Tajra (1994:10) wys daarop dat dit die religieus-politiese beleid van die Julio-Klaudiaanse Keisers was om die stabiliteit van hulle regime te verseker en die wydverspreidheid daarvan tot ' $n$ mate te konsolideer (1994:7) deur die tradisionele Romeinse godsdiens te herstel en om die keiserkultus daarin te integreer. Buiten stabiliteit en eenheid het dit ook die Keisers verseker van " $n$ "primordiale" magsposisie in die funksionering van die Staat. Vanweë die byna absolute mag wat die Keiser hierdeur verkry het, het dit aanvanklik nie sonder teenstand gebeur nie. So byvoorbeeld was die tendens om die Keiser te vergoddelik nie 
populêr onder die Romeinse Senatore ten tye van Octavianus nie. Gevolglik teken hy homself ook eerder as die restoreerder van Republikeinse tradisies. Tog laat hy homself vanaf 42 VCE benaam as divi filius (as seun van Julius Caesar, wat vergoddelik is) en met sy dood in $14 \mathrm{CE}$ verklaar ' $n$ Senaatsdekreet hom tot divus Augustus en beveel aan dat hy saam met die ander Staatsgode gereken moet word. Hoewel dit somtyds lyk of hy afkeurend teenoor sy eie vergoddeliking in die provinsies (sien Jones 1970:150) gestaan het, kan daar min twyfel bestaan dat hy die infrastruktuur daargestel het vir die ontwikkeling van die Keiserkultus ${ }^{3}$. Hierna kan ' $n$ toenemende tendens in die groei van die Keiserkultus aangetoon word. Benewens die titel divi filius, word ook terme soos $\sigma \omega \tau \eta \dot{\rho} \rho$

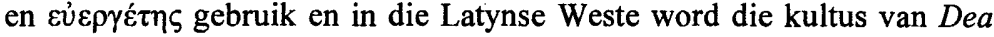
Roma en Augustus bevorder en geassosieer met kwaliteite en toestande soos Victoria, Fortuna Redux en Pax Augustus (Tajra 1994:9).

In die provinsies van die Griekse Ooste het die Keiserkultus bykans onmiddellik na die slag van Actium 31 VCE begin posvat en is dit met toegewydheid omhels. Griekse stede het al teen $29 \mathrm{VCE}$ en of ander vorm van imperiale kultus geïnisieer en die Romeinse provinsies van Bitinië en Asië het gevestigde kultusse gehad met tempels, priesterskap en spele (Fischler 1998:165). In die provinsies van die Griekse Ooste het die Keiserkultus so byval gevind dat ook die vroue van die Keisers in sommige gevalle vergoddelik is. Dit beteken nie dat hulle vergoddeliking aan hulle ooit ' $n$ onafhanklike posisie verseker het nie; die vergoddeliking van die Keiser se eggenote moet altyd gesien word as 'n verlengstuk van sy eie mag, aangesien die Keiserkultus geskoei was op manlike mag. Wat dit egter wel aantoon, is tot watter mate die patriargalisme van die oiko 5 weerklank vind in ' $n$ imperiale ideologie waarmee die Grieke kon saamleef ${ }^{4}$. Terselfdertyd gee dit ook ' $n$ indikasie van die

${ }^{3}$ Elsner (1996:38) wys hoe die Res Gestae bygedra het tot 'n bevestiging van Augustus se imperiale mag en vergoddeliking. Topografies word die Res Gestae geakkommodeer in die Mausoleum van die imperiale familie in die noordelike deel van die Campus Martius. Dit staan daarom naby die Solarium Augusti (Horologium of sonhorlosie) en die Ara Pacis Augustae. Wanneer die sonhorlosie op Augustus se verjaardag direk in die rigting wys van die Ara Pacis Augustae (Scarre 1995:49) kry ons ' $n$ idee van die wyse waarop sy mag in kosmiese dimensies uitgedruk word. Elsner (1996:38) skryf: "The symbolism of time implicit in the Horologium was a counterpoint to the evocations of death and eternity suggested by the Mausoleum and the theme of apotheosis in the Ustrinum". Buiten die talle bouprojekte, waaronder veral ook die restorasie en bou van tempels vermeld word waardeur hy homself met die sakrale assosieer, word die Res Gestae ook betitel as Res Gestae Divi Augusti.

${ }^{4}$ Fischler (1998:166-167) verwys, onder andere, na die verering van Augustus en Livia, Klaudius en Agrippina in Ankyra, Agrippina, Livia en Octavia in Mytilene. In Romeinse Athene word die imperiale familie geïntegreer. Die tradisionele gods- 
geweldige mag wat die Keiser self gehad het - hoewel hierdie vergoddelikte vroue self haas onbeperkte mag moes gehad het. Dit kom tot uiting in die wyse waarop hulle met die sterkste godinne van die Grieke geïdentifiseer was. Dit het net die magspotensiaal van die Keiser versterk, aangesien hulle steeds onderworpe was aan sy wil (Fischler 1998:179).

As iemand nie die nodige eer bewys aan so ' $n$ magtige figur nie, kon hy/sy nie anders as om van die ernstigste misdaad beskuldig te word nie. Enige belediging of kwaadspreek teenoor die Keiser of sy familie is gesien as verraad, die sogenaamde crimen laesae maiestatis (Tajra 1994:4) ${ }^{5}$. Omdat die persoon van die Keiser die hoogste vorm van mag gesimboliseer het, en hy gesien is as verdediger, bewaarder en weldoener van die stad en Ryk, is ' $n$ miskenning van sy status ook as ' $n$ bedreiging vir die gemeenskap gesien. Dit was ' $n$ kwessie van dislojaliteit teenoor die groep. Deur nie gewillig te wees om vir die Keiser te offer nie, of om nie Christus as Koning af te sweer nie, was gelykstaande aan ' $n$ kriminele oortreding waarvan die komponente ' $n$ kombinasie van hoogverraad en blasfemie was. Slegs die ergste straf kon hierop verwag word.

\subsection{Die wraak van die Keiser}

Coleman (1999:45-49) verwys na 'n paar verskillende doelwitte van die Romeinse strafpraktyk gedurende die Imperiale tydperk, te wete, retribusie of wraak, vernedering, verbetering of rehabilitasie, voorkoming en afskrikking.

Ingesluit in die uitoefening van wraak sou ' $\mathrm{n}$ mens iets van die talio beginsel kon sien, waarvolgens die spesifieke strafpraktyk die misdaad na vore moet roep. Hoewel iets van die talio beginsel sou kon geld, moet in gedagte gehou word dat geen simmetrie tussen misdaad en strafpraktyk in die soort rigoristies-hiërargiese Romeinse gemeenskap verwag kon word nie. Die waardes wat die strafpraktyk hier reguleer vereis ' $n$ asimmetriese toestand, want dit is slegs deur die intensiteit van die straf te verhoog dat die "persoon" van die Keiser herstel kan word. Ons het met die status van " $n$ god en met die aantasting van " $n$ "liggaam van volheid" te doen. Omdat die weiering om die nodige respek vir die Keiser te bewys, die verkragting is van " $n$ "liggaam van volheid", is die doel om die totale defektiwiteit van die misdadiger se liggaam te demonstreer. So het die straf op ' $n$ disrespek vir die Keiser, die doel om die liggaam so lank

dienste en Livia en Julia, haar stiefdogter, word byvoorbeeld geassosieer met die godin van die vuurherd, Hestia (Fischler 1998:172-173).

${ }^{5}$ Die wetgewing rondom die maiestatis is uiters ingewikkeld en kompleks en moeilik reduseerbaar tot ' $n$ spesifieke misdaad. Deel van die probleem is geleë in die feit dat die wetgewing reeds vanuit die laat Republikeinse tydperk stam, waar dit geformuleer was om die populus Romanus te beskerm (vgl Bauman 1967 vir 'n uiteensetting van die komplekse ontwikkeling en reikwydte van die wetgewing). 
as moontlik te onderwerp aan die toediening van maksimale pyn. In daardie proses van pyntoediening word die Keiser se "liggaam van volheid" weer herstel.

Omdat dit gaan om die skending van status, moet die veroordeelde misdadiger maksimaal van status ontneem word. Hier is geen sprake van menswaardigheid nie, maar vernedering funksioneer as integrale deel in die motivering van die Romeinse strafpraktyk, en weer eens word die liggaam sentraal gestel. Die doel is om via die vernedering van die oortreder se liggaam die hiërargie van die sosiale liggaam te herstel. Die veroordeelde moet vervreemd word en 'n distansie tussen dié wat tot die sosiale liggaam behoort en dié daarbuite moet gedemonstreer word (Coleman 1990:47). So kan via die pyniging van die liggaam aangetoon word hoe wanordelik dit lyk wanneer die hiërargie van die sosiale orde versteur word. Die vernederingsmotief kan dikwels waargeneem word in die bespotting wat daar van die veroordeelde gemaak word.

Ongetwyfeld het die toediening van maksimale pyn, en die skande wat daarmee gepaard gaan, die doel om af te skrik (Coleman 1990:48). Vir effektiewe afskrikking moet 'n strafpraktyk egter in die openbaar geskied.

Hoe is hierdie motiewe in die strafpraktyk gekonkretiseer? Die uitoefening van Romeinse strafpraktyk is ' $n$ konkrete oefening in wat Foucault (1977:26) 'n "micro-physics of power" genoem het. Wat ter sprake is, is " $n$ strategie van mag waarmee die liggaam brutaal en fisies "gemerk" word om die rigoristiese hiërargieë van die Romeinse gemeenskap te handhaaf. Straftoepassing in die Romeinse imperiale Ryk mag strek vanaf tatoëring, slae, ballingskap, harde arbeid tot by marteling en die dood, maar in die uitoefening van straf funksioneer die pyniging van die liggaam telkens om die sosiale orde te bevestig en te versterk.

Die deurlopende beginsel vir die toepassing van straf was nie die misdaad self nie, maar eerder die sosiale kragte wat ter sprake was in die spesifieke situasie. So byvoorbeeld was die sosiale status van die misdadiger ' $n$ belangrike kriterium vir die soort straf wat uitgeoefen was. Hoedanig die liggaam gekonstrueer was deur die diskursiewe patrone van die dag, het ook die soort pyniging, lyding en mishandeling daarvan bepaal. Omgekeerd het die manier waarop die gemeenskap sy tekens gelaat het op die liggaam gefunksioneer as ' $n$ indikasie van die sosiale status. Die liggaam was ' $n$ ruimte waarop geredelik sekere boodskappe aan en deur die gemeenskap gesein kon word. Op 'n slaaf se lyf is daar ' $n$ bepaalde merk gemaak om aan almal sy statusloosheid te toon. En hierdie permanente liggaamlike merk sou dwarsdeur sy lewe, verdiend of onverdiend, sy posisie in die gemeenskap bepaal. Volgens die lex Aelia Sentia (4 C E) kon slawe, wat om 'n verskeidenheid van redes getatoëer was, by vrystelling slegs die status van "buitelanders wat oorgegee het aan die Romeinse staat" bekom. Hulle kon dus nie volle burgerskap met volledige 
politieke regte verkry nie en het so die laagste moontlike vlak van vrye nie-burgers uitgemaak (Gustafson 1997:87). Harde arbeid, slae en besondere wrede vorme van teregstelling was die strawwe wat toegepas was op slawe en mense van besondere lae status.

' $n$ Verskil in strafpraktyke is gemaak tussen die honestiores en humiliores ${ }^{6}$. Ten spyte daarvan dat die humiliores vrye burgers was, kon hulle hul eiendom, erfreg en vrye burgerskap verloor het en so servi poenae geword het. Verder kon hulle met 'n stok geslaan word, vasgeketting en ook getatoëer word (Gustafson 1997:87). Vir die honestiores het hierdie strawwe nie gegeld nie. Slegs in die geval waar hulle ook die maiestas van die Keiser aangetas het, was daar geen vryspraak vir hulle moontlik nie (Coleman 1990:55). So gewelddadig het die Romeinse gemeenskap hulle hiërargiese ordening op liggame geskryf dat die liggaam van 'n honestior letterlik iets anders was as die liggaam van ' $n$ humilior. Die humiliores se liggame kon vir ' $n$ lang tyd aan maksimale pyn blootgestel word alvorens hulle doodgemaak is - die liggame het geen dignitas gehad nie en deel van die strafpraktyk wat op hulle van toepassing was, was die feit dat hulle met minagting behandel moes word. Vir die Romeinse gemeenskap was dit natuurlik, toepaslik, regverdig en glad nie slegte smaak dat die soort liggame aan die grofste vernederings blootgestel word nie (Coleman 1990:57). Trouens, dit moes so gebeur, want daardeur word die superioriteit van die Romeinse burger se liggaam bevestig en by implikasie ook die vergoddelikte liggaam van die Keiser. Selfs in die uitoefening van die doodstraf het die gemeenskap sy hiërargiese ordeninge en magsrelasies op die liggaam geskryf. So byvoorbeeld het ' $n$ Romeinse burger die voorreg gehad om met die swaard doodgemaak te word, terwyl marteling en strawwe, soos om met vuur verbrand, vir wilde diere gegooi te word, en gekruisig te word vir nie-burgers verseker is. Dit beteken egter nie dat hier met ' $n$ hoë mate van konsekwentheid gereken kon word nie, aangesien die cognitio extra ordinem ('n regsondersoek buite die reël) 'n groot mate van buigsaamheid en daarmee saam ook willekeurigheid verseker het (Gustafson 1997:88; Tajra 1994:19).

Omdat die misdadiger, skuldig bevind op aantasting van Keiserlike gesag, terselfdertyd skuldig was ook aan hoogverraad, ten diepste ' $n$ bedreiging ingehou het vir die orde en welvaart van die gemeenskap, het sy/haar liggaam ' $n$ plek geword waar die chaotiese van maatskaplike

\footnotetext{
${ }^{6}$ Die onderskeid in strafpraktyk tussen dit wat geld vir humiliores en honestiores blyk terug te gaan na die tyd van Hadrianus (Coleman 1990:55). Die onderskeid tussen die twee groepe was nie waterdig nie en terwyl die humiliores waarskynlik vrygemaakte slawe en nie-Romeinse vry burgers ingesluit het, kon "lidmaatskap" gewissel het en blyk dit afhanklik te gewees het van eiendom, mag en reputasie (1990:57).
} 
wanorde gedemonstreer kon word. Omdat die goddelike persoon van die Keiser aangetas is en daarmee die absolute eer wat aan hom verskuldig is, het hy die reg gehad om die aantasting van sy persoon te wreek en so imperiale mag te bevestig.

\subsection{Die "spektakel"? van die arena en amfiteater}

Die spektakulêre van die amfiteater kon die mag van die Keiser doeltreffend bevestig. Tog was dit ook die konteks wat ruimte gelaat het dat ' $n$ disassosiatiewe meganisme in werking gestel kon word ${ }^{8}$.

In watter opsig het dit die mag van die Keiser bevestig? Die ontstaan en ontwikkeling van Romeinse "spektakels" val saam met die ontwikkeling in mag van Imperiale Rome en die bevestiging van daardie mag deur fisiese geweld. Die "spektakels" van die arena was nie die enigste soort nie, maar groot seegevegte (naumachia) is ook gehou. Volgens Suetonius word onder Klaudius ' $n$ seegeveg gesimuleer waarin 19 000 mense sou sterf (sien Coleman 1990:71). Die liggame wat hoofsaaklik vir hierdie soort slagting gebruik was, was die van krygsgevangenes of veroordeeldes, en sekere meganismes is ingestel om te verhoed dat daar enige ontsnapping moontlik kon wees.

Enige "spektakel" bestaan egter, onder andere, uit twee integrale komponente, naamlik ' $n$ visuele en ' $n$ narratiewe. Die narratiewe omraam, verduidelik en interpreteer die visuele. Dit gee betekenis aan die visuele. Hierbenewens moet die "spektakel" ook publiek wees - trouens "n "spektakel" moet "gekyk" kan word (Michie 1992:12). Dit is daarom bykans wesentlik deel van die "spektakel" dat die intieme en private in die publieke uitgestal word. Wanneer die "spektakel" herhaal word, ontwikkel 'n addisionele element, naamlik die rituele. Die rituele funksioneer om groepsolidariteit te bewerkstellig en te versterk. In die Romeinse gesimuleerde seegevegte, asook in die arena en amfiteater kom al hierdie elemente van die "spektakel" bymekaar.

Anders as in die gewone teater, word die visuele in die arena en die amfiteater tot die uiterste gevoer. Wat hier afspeel, is nie gewoon maar net ' $n$ storie nie, maar word geaktualiseer tot "werklikheid" - die storie word waargemaak. Die reservoir wat stories voorsien het, was aan die

\footnotetext{
${ }^{7}$ Met "spektakel" word verwys na wat in Engels genoem word "spectacle". Hoewel dit vreemd op die Afrikaanse oor mag val, druk dit tot ' $n$ sekere mate beide die aanskoulike, maar ook die bespotlik sensasionele wat deel uitgemaak het van die Romeinse arena, beter uit en daarom word verkies om by hierdie vertaling te bly.

${ }^{8}$ Disassosiasie moet hier in die sin van Perelman \& Olbrechts-Tyteca (1969) verstaan word, naamlik dat daar by ' $n$ heersende stel waardes aangesluit word, maar dat binne so ' $n$ raamwerk ' $n$ herdefinisie voorsien word. In hierdie spesifieke geval word geargumenteer dat dit wat gesien is as die superieure aggressiewe Romeinse man so sterk gevestig was dat ' $n$ identifikasie daarmee die moontlikheid gebied het vir "martelaarskap", vir die konstruksie van "superhelde".
} 
een kant die geskiedenis en aan die ander kant die mitologie, en gevegte tussen "Tiriërs" en "Egiptenaars", tussen "Atheners en Persiërs" het "werklikheid" geword in die Romeinse "spektakel" (Coleman 1990:71). Die "werklikheid" wat hier tot stand kom, is egter een van brutale geweld, van 'n onkeerbare aggressie - vir 'n moment word die demper gelig van die filosofies en mediese eis van kontrole en van gematigdheid, en in die dodelike spel met liggame word die werklikheid van hiërargie, gewelddadigheid, militarisme, ekonomie, lyding, oorwinning uitgebeeld.

Tussen diegene wie se liggame onderwerp word aan intense pyn en lyding en uiteindelike dood in die arena en diegene wat aanskou, bestaan 'n duidelike skeidslyn. Húlle daaronder, is nie ons nie, maar ons kan hulle laat doen wat ons wil. Sou dit krygsgevangenes wees, kan daar dubbel tot hulle vernedering bygedra word deur hulle hulle eie neerlaag te laat aanbied (Coleman 1990:72). Die mees private moment in elke mens se lewe, die dood, word hier vermaak. In die sfeer van die publieke oog - en tot die vermaak van die toeskouers - word dit deur prosesse van marteling verleng. Deur elke "teater van pyn en dood" word daar aan die Romeinse burger die geleentheid gebied om met die brutale mag van Rome te identifiseer en telkens word elke hiërargie van die Romeinse gemeenskap weer bevestig. Die openbare karakter van die arena en die fisiese rangskikking van die amfiteater, met sy verdeling tussen diegene wat kon sit en diegene wat moes staan en die besondere prominente plek wat aan die Keiser of aan sy verteenwoordigers gebied het, graveer by elke opvoering weer eens die magsrelasies van die Romeine in die imperiale tydperk op die liggame van die teenwoordiges.

Intussen staan die Keiser nie alleen aan die bopunt van die hiërargie nie; hy simboliseer absolute mag - dit is immers hy wat deur sy wonderwerkende krag die tradisie waaruit die Romeine stam tot "werklikheid" maak. Benewens die feit dat sy militêre bevoegdheid en politieke vermoë telkemale bevestig word deur die skouspel in die arena, is hy ook die een wat in die "plesier" van sy onderdane kan voorsien. Strafpraktyk en openbare ontspanning val saam in die amfiteater - krygsgevangenes kry hulle verdiende loon, en die uitgerekte marteling en dood van veroordeeldes bevestig die Romeinse regsisteem. Deur hierdie "estetiese" en "regsmoment" word barbare van burgers onderskei!

Daar moet in gedagte gehou word dat die hou van hierdie "spektakels" ' $n$ taamlike infrastruktuur moes gehad het. Daar moes ' $n$ deurlopende stroom van "karakters" wees in die liggame van krygsgevangenes, slawe, veroordeeldes, humiliores, gladiators in al die verskillende vorme, asook die nodige apparatuur vir die opvoering van gevegsvorme. Hierbenewens moes diere nie alleen aangehou word nie, maar ook ingevoer word, en moes daar die nodige beskerming aan die toeskouers verseker kon word. Hiervoor was grootskaalse finansiële befondsing nodig. Hoe 
groter die skaal waarop die "spektakel" aangepak was, des te groter het die reputasie van die Keiser of sy verteenwoordigers geword.

\subsection{Die liggame van Christenmartelare in die oorlogsmasjien van die Romeine}

In heelwat kontemporêre literatuur word verklaar dat dit nie baie duidelik was wat die rede was waarom Christene aangekla en vervolg was nie. So ' $n$ onduidelike toestand maak dit natuurlik moontlik dat die Romeine van ' $n$ tipe willekeur beskuldig kon word, en word die indruk geskep dat die Christene slegs onskuldige slagoffers was. Daar moet egter in gedagte gehou word dat die onderhoud van vrede en orde in die Imperiale tydperk prioriteit geniet het, en vrede, orde, welvaart was alles sake wat op een of ander wyse aan die Keiser en die Romeinse volk se gode verbonde was. Hoewel dit problematies sou wees om die veroordeling van Christene pertinent aan die crimen laesae maiestatis te verbind, vorm dit die breë regskonteks wat dit moontlik sou kon maak om gronde te verskaf vir die tot dood veroordeling van Christene. Ongetwyfeld het hierdie vorm van wetgewing in samewerking met wette soos die coercitio, cognitio extra ordinem en contumacia gefunksioneer (sien Musorillo 1972:Ivii-lxii).

Dat daar onsekerheid was oor hoe daar oor die Christene opgetree moét word, kan duidelik uit die korrespondensie tussen Plinius en Trajanus gesien word. Buiten die "hoe" van die straf, is Plinius onseker oor presies "wat" as strafbaar sou kon geld. Daar is egter die vermoede of suspisie dat daar ' $n$ religieus-politiese gevaar mag bestaan, aangesien die Christus kultus wydverspreid voorgekom het, en aangesien daar ' $n$ hardkoppigheid onder die Christene bestaan om nie in die herlewing van die tradisionele godsdienste te deel nie. Die toets wat Plinius aangelê het, wys egter dat die misdaad van die Christene binne die konteks van ' $n$ bedreiging vir die persoon van die Keiser, en daarom ook vir die welvaart van die gemeenskap verstaan kan word. Kortliks kom die verhoor op die volgende neer. Plinius vra of ' $n$ persoon ' $n$ Christen is; die vraag word vir ' $n$ tweede of selfs derde maal herhaal met die waarskuwing van straf. Indien geen antwoord verskaf word nie, word so ' $n$ persoon tereggestel. Waar Christenskap ontken word, word dit getoets en die toets behels dat ' $n$ formule herhaal moet word waarvan die inhoud met die aanroepe van gode te doen het en dat daar ' $n$ offer vir die standbeeld van die Keiser gemaak moet word.

In die antwoord wat Trajanus aan Plinius verskaf, blyk dat die weerstand om deel te hê aan die Keiserkultus gesien word as ' $n$ strafbare misdaad. Terselfdertyd word gemaan om nie ' $n$ grootskaalse "Christenjag" op tou te sit nie en om by " $n$ belydenis van die misdaad, nie suspisie te laat geld as gronde vir veroordeling nie (Plinius, Ep. Tra. 10, 96-97). Bisbee (1988:99) som die posisie korrek op: "The fact is that no matter 
how much the apologists denied it, the martyr mentality was often guilty of treason, for it regarded the Empire as Satan's puppet, and accordingly many of the Christians actively sought to tear it down, even if it meant throwing themselves headlong into the machinery of the empire" (sien ook Gustafson 1997:88)

Omdat die nie-onderhandelbare waardes van die gemeenskap tydens die Imperiale tydperk bedreig is, moes die Imperium reageer en die liggame van Christene het die ruimte geword om die absolute mag van die Keiser en by implikasie die Romeinse volk te demonstreer. Deur die mees radikale en intense vorme van liggaamsmishandeling en vernedering word die eer van die Keiser herstel. Deur die soorte straf waaraan die Christene onderwerp was, wat gewissel het van die fisiese merk van die liggaam deur tatoëering en brandmerke (waarskynlik die gesig), tot by die verskeur deur diere, word telkens die onaantasbaarheid van Romeinse waardes bevestig. Die stelselmatige aftakeling, vernedering en vernietiging van die liggaam word ' $n$ advertensie van die grootsheid van imperiale mag (sien ook Gustafson 1997:89). Die taalmatig gestruktureerde hiërargie van die Romeinse samelewing bepaal die intensiteit van die marteling en die dood (vgl Coleman 1990:46; Tajra 1994:22). So byvoorbeeld word Christene met Romeinse burgerskap steeds met die swaard, as simbool van die absolute Romeinse militêre mag gedood, terwyl verbranding (crematio, ook bekend as vivicomburium), die wilde diere (ad bestias) of die kruisiging vir die minderwaardiges gewag het. Anders as in moderne gemeenskappe is die doel nie om die daad te straf nie, nie om ' $n$ simmetrie tussen misdaad en straf te bewerkstellig nie, maar om in die totale, langsame vernietiging van die liggaam, die persoon van die ander te herstel. Marteling is nie ' $n$ vorm van straf in die antieke nie, maar is die strafpraktyk. Omdat die klem geval het op maksimale pyn, die uitstel van die dood, totale vernedering en die verwydering van menswaardigheid, kon daar ook ' $n$ kombinasie van strawwe toegedien word.

Die biskop van Smirna vertel byvoorbeeld in die brief wat hy skrywe aan die kerk in Filomelium dat martelare so geslaan is dat hulle slagare en are blootgelê was (Mart. Pol 2.2), verwysings word gemaak na Christene wat verbrand is (2.3), en dit blyk dat van die damnati ad bestias oor die skerp punte van skulpe getrek was alvorens hulle aan die wilde diere oorgelaat is (2.4). In die martelaarsverhaal van Perpetua en Felicitas word hulle manlike medemartelare, naamlik Revocatus, Saturninus en Saturus, eers deur ' $n$ dubbele ry van gladiatore of venatores geslaan omdat hulle die gevestigde gesag van die goewerneur beledig deur gebare en dreigemente (sien Mart. Perpet. Felic. 18.15; Shaw 1993:5).

${ }^{9}$ Venatores verwys na die "jagters" van wilde diere in die amfiteater. 
Ons het gesien dat vernedering deel uitmaak van die strafmotief. Integrale deel daarvan is bespotting. So kan daar soms in die martelaarsverhale spore van sodanige bespotting aangetref word. Byvoorbeeld: pogings word aangewend om Perpetua en Felicitas te dwing om die gewaad van Ceres se priesteresse aan te trek terwyl hulle martelaarsgenote geforseer word om Saturnus se priestermantels te dra. Perpetua weier natuurlik, maar die strafpraktyk om te verneder deur bespotting kom tot uiting in die wyse waarop gepoog word om Perpetua en haar martelaarsgenote, vanweë hulle weiering om die tradisionele Romeinse gode te erken, dan self tot offerandes van die god en godin van saai- en oestyd te maak (Coleman 1990:66; Shaw 1993:5; Vierow 1999:609). Vernedering deur bespotting blyk verder in hierdie martelaarsverhaal uitgebeeld te word deur ' $n$ waansinnige koei in te stuur om Perpetua en Felicitas aan te val (Mart. Perpet. Felic. 20.1). Dit blyk uit ander voorbeelde van vroue wat in die arena gemartel word dat die gebruik van 'n bul of vir die doeleindes van deurboring of bestialiteit nie ongewoon was nie (Coleman 1990:64) ${ }^{10}$. Vroue is naak op ' $n$ paal vasgemaak en dan aan die vermorseling van ' $n$ bul onderwerp. Daar is geen twyfel aan dat beide hulle naaktheid, asook die onderwerping aan ' $n$ bul simbolies moes figureer om nie alleen seksuele suggesties te wek nie, maar ook om vroue se seksualiteit bespotlik te maak. In die geval van Perpetua en Felicitas word hulle seksualiteit bespotlik gemaak deur ' $n$ dier van soortgelyke seksualiteit te gebruik om hulle te vernietig. So word hulle dan ook gelyk gestel aan die diereryk (en in hierdie geval selfs ' $n$ abnormaliteit in die diereryk!) en daarmee verwyder uit die hiërargie van mense (Shaw 1993:7; Vierow 1999:611).

Perpetua het uit ' $n$ familie gestam wat waarskynlik Romeinse burgerskap gehad het. Blandina is egter ' $n$ slavin wat saam met die ander martelare van Lyons herhaaldelik aan marteling onderwerp word ${ }^{11}$. Ongeag die historiese akkuraatheid van die verhaal as sodanig kan weer eens gesien word hoe die toediening van maksimale pyn, die uitrek van die folteringstydperk en doelbewuste vernedering deel uitmaak van die wyse waarop Imperiale mag op liggame gevestig word deur strafpraktyk. Pertinent word Blandina se minderwaardige status as slavin vermeld (1.17). Dit stel haar natuurlik bloot aan die mees intensiewe strafvorme, en dit blyk dan ook uit die herhaalde wyse waarop sy aangerand word. Haar folteraars staan verbaas dat sy nog kan asemhaal, aangesien haar hele liggaam gebreek en geskeur was (1.18). Later word sy aan 'n paal

\footnotetext{
${ }^{10}$ Sien ook Acta Theclae (3.35) waar Thecla tussen bulle vasgemaak word en hulle dan op hulle genitalieë met rooiwarm ysters gebrand word. In die geval van damnatus ad bestias was dit onder andere ook strafpraktyk om die slagoffers aan ' $n$ bul vas te maak.

${ }^{11}$ Sien The martyrs of Lyons, in Musurillo, (1972) 62-85.
} 
vasgemaak en aan die diere blootgestel wat op daardie stadium weier om haar aan te val (1.40). En dan as kulminasiepunt op die laaste dag van die gladiatore word sy weer ingebring in die arena en nadat sy geslaan en gebraai is, is sy uiteindelik in ' $n$ net gegooi en ontbloot vir ' $n$ bul (1.56).

\subsection{Die politieke bemagtiging van die vroeg Christelike martelaar se liggaam}

Die wyse waarop die politieke strategieë van 'n gemeenskap op die liggaam geskryf word, word egter nie uitgeput deur die magsontplooiing van die Imperiale Ryk op die liggame van die vroeë Christene nie. Die liggaam, gesien binne ' $n$ politieke tegnologie, staan nooit in 'n magsrelasie waar mag uit en uit in een pool gekonsentreer word nie. Trouens die blote feit dat daar weerstand in die vroeë Christendom gebied is teen die Imperiale Ryk, wetende dat die liggaam die ruimte sou wees waarop die woede van die Imperium losgelaat sou word, is reeds tekenend van ' $n$ aktualisering van mag. Die liggame van die martelare word egter ook op ' $n$ ander wyse deel van ' $n$ politieke tegnologie. Nie alleen funksioneer die liggame van die martelare om groepsolidariteit onder die vroeë Christene te bewerkstellig nie, maar die gebreekte en geskende liggame van die martelare word aangewend as ' $n$ strategie om die groepsolidariteit te versterk met heersende waardes rondom die superieure man. Grondliggend aan die martelaarsverhale is nie ' $n$ afkeur van die gewelddadigheid nie, maar eerder ' $n$ gelate aansluiting daarby om aan te toon dat die Christen eer verkry deur ' $n$ vrywillige aanvaarding en verduring van die afgryslikste liggaamlike lyding. Die nalatenskap van die "spektakel" word verder gedra; die voorwaardes wat dit moontlik kon maak dat gebeure soos die "spektakel" vir bykans vierhonderd jaar kon plaasvind, genereer ook die martelaarsverhale en verklaar hulle populariteit.

Die martelaarsdiskoerse van die vroeë Christendom sluit aan by die paradoksale, aggressiewe en brutale figuur van die gladiator. Aan die een kant kan die gladiator as man sonder enige waarde beskou word, 'n uitvaagsel van die gemeenskap. Barton (1989:2) beskryf die gladiator as: "crude, loathsome, doomed, lost (importunus, obscaenus, damnatus, perditus)"; dit was ' $n$ man "utterly debased by fortune, a slave, a man altogether without worth and dignity (dignitas), almost without humanity". Aan die ander kant was die gladiator die kulminasiepunt van aggressiewe, gewelddadige, fisiese manlike gedrag. Aanvanklik word die gladiator geledere alleenlik aangevul deur veroordeeldes en die oorwonnes, maar teen die einde van die Republiek was ongeveer helfte van die gladiators reeds vrywilligers. Teen die helfte van die eerste eeu was meer as die helfte vrye burgers $(1989: 2,25)$. Ten spyte van ' $n$ byna sekere gewelddadige dood groei die getalle van die gladiators. 
Die model van die gladiator verskaf ' $n$ tegnologie van die liggaam wat status in ' $n$ desperate situasie kan verskaf. In ' $n$ sekere sin funksioneer dit as ' $n$ katalisator wat die geslagtelikheidshiërargie onderliggend aan sosiaal-politiese relasies na die oppervlakte bring. Trouens dit is omdat die wêreld van die Imperiale Ryk deur ' $n$ manlik gedomineerde geslagtelikheidshiërargie deursuur was, wat die model van die gladiator as ' $n$ metafoor van bemagtiging kon dien.

Deur die aflegging van die sogenaamde gladiator eed (sacramentum gladiatorum) word ' $\mathrm{n}$ verandering in die desperate en minderwaardige situasie van die gladiator bewerkstellig. Sy eer bestaan, kragtens die aflegging van die eed, daarin om verbranding, gebondenheid, slae en die dood deur die swaard te verduur (Barton 1989:3). Die aflegging van die eed beteken om onder die verpligting van self-destruksie te staan, maar dit is die gekontroleerde erns en toewyding aan die rol wat eer ingehou het. Om nie aan hierdie verpligting trou te wees nie, sou oneer beteken. Hoewel die gladiator in absolute getrouheid staan teenoor die een wat hom besit, verkry hy deur hierdie eed weer beheer oor homself. Dieselfde liggaam wat deur die gemeenskap ' $n$ posisie van oneer aangewys is, kan ' $n$ ruimte wees waarop eer herstel kan word.

'n Sleutelbegrip in die model van die gladiator is die van "vrywilligheid", die strewe om gewilliglik die dood tegemoet te gaan (amor mortis). Die vermoë van te "kan wil", om "gewillig te kan wees", die potestas van wil hoort sentraal tot die ideologie van manlikheid (1989:3). Eer lê dan daarin om te weet dat pyn publiek verduur sal moet word en dat die dood sal volg, maar om dit desnieteenstaande te omhels. 'n Liggaamstegnologie ontwikkel wat die wyse van sterf en die manier waarop pyn verduur kan word omskryf in deugdelikheid. In die wêreld van die eerste eeu bestaan 'n baie dun grens tussen vis (mag) en virtus (deug). In die gedagte van gewillige self-destruksie kan deug teruggevind word. Deur homself gewilliglik aan self-destruksie oor te gee, word die gladiator herstel tot ' $\mathrm{n}$ posisie van uitermatige eer - hy word ' $\mathrm{n}$ miles sacratus en sy knegskap word verander in publieke diens (Barton 1994:52). Tydens die imperiale tyd is dit juis hierdie vertoon van heroïese manlikheid wat die populariteit van die gladiator verseker en ' $n$ sekere adel restoreer, binne 'n konteks waar Keiserlike mag, vrygebore, aristokratiese burgers gedwing het tot kniebuigende navolgelingskap (Barton 1989:9). Met die verbygaan van die Republiek het dignitas, oftewel sosiale waarde, ' $n$ woord geword waarvan die inhoud niks meer as vernedering ingehou het vir die vrye en bevoorregte klasse van Rome nie. Barton skryf (1989:11): "The traditional testimonials of power, freedom, and pride began to signal as well powerlessness, enslavement, and humiliation". Die gladiator wat regop en fier in 'n desperate, wrede en harde stryd, die dood vrywillig tegemoetgaan aktualiseer ' $n$ model van heldhaftige manlikheid waarmee die toeskouers in die arena kon identifiseer. 
' $n$ Verdere komponent in die struktuur van die gladiatormodel, is

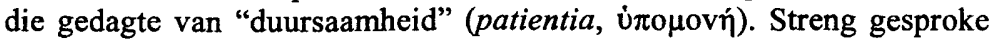
behoort hierdie deug eintlik tot die passiewe wêreld van vroue, komende vanuit die proses van pyn en lyding tydens swangerskap en geboorte. Shaw (1996:285) skryf: "The polarization of ideals engendered by the emergence of the politicized city-state constructed males as persons who had bodies that stood erect, inflicted pain, and died on the field of battle; female ones as suffering bodies, lying prone, giving birth in bed. Conceptions of civic bodies were therefore attached to specific barometers of pain and resistance". " $n$ Ontwikkeling vind egter plaas wat hierdie origens vroulike deug in ' $n$ manlike deug verander via assosiasie. Deur $p a$ tientia, met die vermoë van ' $n$ vrou om haar liggaam soos die van ' $n$ man te beheer, word die "vroulike" deug in die wêreld van mans ingetrek en positief geëvalueer. So kan Seneca dan byvoorbeeld "duursaamheid" as 'n sekondêre deug van vroulikheid herken, maar die moontlikheid laat van "dappere duursaamheid" wat met atlete en met diegene wat politiese marteling verduur geassosieer kan word (1986:295)! Duursaamheid beweeg so van ' $n$ passiewe na ' $n$ aktiewe modus. Mans in ' $n$ desperate situasie kan dus kies vir die deug van duursaamheid en sodoende weer beheer verkry.

Talle voorbeelde kan aangetoon word om die verband tussen vroeg Christelike martelare en die gladiatormodel mee aan te toon ${ }^{12}$. In ' $n$ sekere sin was daar ook ' $n$ historiese noodwendigheid wat hierdie verband bewerkstellig het en dit kan gevind word in die publieke marteling van die martelare in die spektakulêre van die arena. Dit is dramaties ironies dat die "spektakel" waar burgerlike en keiserlike eer via die martelaarsliggaam herstel moes word, terselfdertyd die ruimte word waar die martelaarsliggaam, vermink en geskend, eervol uit die stryd kan tree. Bowersock (1995:50) beweer tereg dat "in the manner of their (die martelare) dying their fame was far closer to that of the great athletes and gladiators". Hy wys daarop dat hierdie dood juis plaasvind in die "spektakel" van die amfiteater, maar dat dit nie "n nuwigheid was nie die "spektakel" en die "spel" van die martelare sluit aan by reeds bestaande sosiale ordes. Dit is voorts ook belangrik om daarop te let dat die "spektakel" van die amfiteater nie in isolasie, maar in die publiek en in die stede afspeel. As sodanig verskaf dit 'n openbare burgerlike rol, nie

\footnotetext{
${ }^{12}$ Hiermee word nie bedoel dat die model van die gladiatore die enigste is nie (sien byvoorbeeld Bowersock 1995:50, wat Polycarpus sien as sofistiese leermeester). Eerder gaan dit om die martelare te sien binne ' $n$ bepaalde geslagtelikheidsraamwerk wat ten doel gehad het om hulle as superhelde, as helde, as superieure mans te sien. Hiervan is die model van die gladiatore die mees toepaslike omdat dit ook binne die konteks van die arena gefunksioneer het en omdat die liggaam so prominent figureer as ruimte vir die afdruk van magsrelasies.
} 
alleen aan die gladiatore nie, maar ook aan die martelare. In bykans elke martelaarsverhaal word die teenwoordigheid van 'n skare vermeld, somtyds in simpatie teenoor die martelare terwyl by ander geleenthede weer in vyandiggesindheid. Ongeag die wyse waarop hulle ' $n$ rol speel in die verhale self, die publieke aard van die martelingsproses kon nie anders as om bekendheid te verleen het aan die Christelike gemeenskap nie. In ' $n$ wereld waar die dood nie alleen 'n gedurige, openbare karakter gedra het nie, maar ook doelbewus nagestreef is, moes dit ' $n$ indruk gemaak het. In 'n sekere sin veroorsaak die openbare, stedelike karakter van die vroeg Christelike martelaarskap dat daar ' $n$ sigbaarheid aan hulle verskaf word wat kontra-produktief gestaan het ten opsigte van Imperiale intensies (1995:42).

Binne die konteks van die spektakulêre word die vroeg Christelike martelare byna konsekwent met die gladiatormodel vereenselwig, selfs daar waar teen die "spektakel" gepolemiseer word". Vir die vernederde en gedegradeerde liggame van veroordeelde Christene word die assosiasie met die gladiator ' $n$ strategie van bemagtiging. Christenmartelare word, via die liggaam in pyn, aristokrate. In die martelaarsverhaal van Polykarpus word die martelare telkemale met beskrywing $\gamma \varepsilon v v \alpha i ̂ \varsigma$ verbind (sien Mart. Pol. 2.1, 2 (tweekeer); 3.1, 2) en dit is duidelik dat die kriterium vir hulle superieure status lê in hulle vermoë om te verduur (Mart. Pol. 2.2, 3, 4; 3.1; 13.3; 19.2). Hierbenewens is hulle netso doodsveragtend soos die gladiatore (2.3) en Germanicus gaan selfs verder deur die wilde dier op homself met geweld te trek (3.1). En wanneer Polycarpus die arena binnegaan, word hy aangemoedig deur ' $n$ hemelse stem om "sterk te wees" en homself op " $n$ "manlike wyse" te gedra (9.1). Hier hou dit egter nie op nie, want netsoos die gladiatore "regop en fier" onoorwinlik hul dood moes tegemoet gaan, het Polykarpus nie nodig om met spykers vasgemaak te word nie - hy sal regop bly (13.3). Telkemale word ook herinner aan die suksesvolle burgerlike rol wat Polycarpus gespeel het $(5.1 ; 10.2 ; 17.1 ; 19.1)$.

Dieselfde tendense kom ook by ander martelaarsverhale voor. In die Martelare van Lyons byvoorbeeld, word vermeld dat die aanvalle van die "Bose" deur نं (sien ook 1.20 in verband met Sanctus) word dit verbind met $\gamma \varepsilon v v \alpha i \omega \zeta$; Vettius Epagathus, wat na vore kom om die martelare te verdedig, word weer eens in terme van sy voortreflike burgerskap beskrywe (1.9). Net

\footnotetext{
${ }^{13}$ Tertullianus sal byvoorbeeld in De Spectaculis te velde trek teen die "spektakel" omdat dit deurtrek is met die gebruike van die tradisionele Romeinse godsdienste en terselfdertyd ook die aanskoue van gladiator-, jagters- en strydwageveg afkeur (sien veral Tertullian, Spect. 21-23 [Roberts \& Donaldson]) en terselfdertyd sal hy die martelaar bemoedigend in die posisie van die gladiator stel en die "spektakel" konteks laat betekenis gee aan die rol van die martelaar (sien Tertullian, Mart. 1).
} 
voordat die martelare die amfiteater binnegaan, word hulle beskrywe as "edele atlete" (1.36), wat " $n$ briljante "stryd deurstaan het" (1.36) en dan word Maturus, Sanctus, Blandina en Attalus die amfiteater ingelei om 'n "spektakel" aan die skare te gee (1.37) en die manier waarop hulle die marteling verduur, is asof hulle hul teenstander in menigte gevegte oorwin het en nou vir die oorwinnaarskrans veg (1.38). Welliswaar domineer die "atleetmetafoor", maar in samehang met die vegter; die punt is egter dat die amfiteatermetafore bemagtigingtegnieke vir die martelaarsliggame word ${ }^{14}$.

Integrale deel van elke martelaarsverhaal is die belydenis of die getuienis. Dit kan in 'n positiewe sin wees, soos wanneer daar direk 'n verbintenis met Jesus Christus bely word, of wanneer gewoon bely word: "Ek is " $n$ Christen". Maar dit kan ook in negatiewe sin gebeur wanneer geweier word om vir die Keiser te offer of eer aan sy beeld te bewys. Die belydenis kan as ' $n$ deklaratiewe taalhandeling gesien word - dit verander die konkrete situasie, want dit bring self-destruksie mee. As 'n strategie binne die raamwerk van 'n politieke tegnologie van die liggaam het dit ' $n$ besondere radikaliteit omdat hiermee die dood verkies word. Foucault (1988:44) maak hierdie belydenis die model vir alle soorte belydenisse, want in hierdie belydenis word "selfopenbaring tot self-destruksie". Die belydenis het egter niks met die tradisionele "sonde" verbintenis te doen nie - dit is polities, en dit is " $n$ strategie waarmee status herstel word. Dit veronderstel ' $\mathrm{n}$ amor mortis, " $\mathrm{n}$ vrywillige toe-eiening van die dood, ' $n$ minagting vir die gedegradeerde liggaam, en ' $n$ vrywillige, maar "edele" verduur van sekere lyding. Hiermee korrespondeer dit met die gladiator se eed, die sogenaamde sacramentum gladiatorum.

\section{KONKLUSIE}

Uit die voorafgaande het dit duidelik geword dat die martelaarskappe van die vroeë Christendom nie net in terme van ' $n$ "getuienis vir die waarheid" of " $n$ "sterf vir die waarheid van die evangelie" gesien kan word nie. Dit is heelwat meer kompleks en moet eerder in terme van ' $n$ politieke tegnologie van die liggaam verstaan word. Nie alleen was die liggame die ruimte waarop die Imperiale mag onmiskenbaar wreed geskryf het nie, maar ook die vroeg Christelike gemeenskappe, in hulle pogings om status aan die Christus kultus te gee, gebruik die liggame van die martelare. Om ' $n$ staanplek in die rigoristiese geslagtelikheidshiërargie van die antieke wêreld te verkry, word 'n kontinuilteit gesoek

\footnotetext{
${ }^{14}$ Die voorbeelde kan vermeerder word. Hier word slegs ' $n$ paar genoem ter wille van die argument. Interessant is ook die geval van Perpetua waar sy haarself in ' $n$

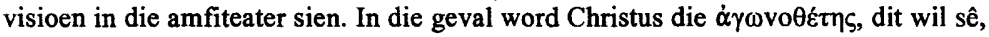
die aanbieder of organiseerder van die spele en Perpetua self word vegter in die spele (Passio Perp. et Felic. 10.8-14; ook Bowersock 1995:51).
} 
en verkry met publieke superhelde van die antieke wêreld. Die gewelddadigheid van hierdie konteks skrik nie die vroeë Christene af nie, en het waarskynlik ook nie dieselfde weersin gewek as wat ons vandag daarteen het nie, want die waardes grondliggend aan hierdie gewelddadige wêreld word gekontinueer in die martelaarsverhale.

Scarry (1985:14) toon aan dat die problematiek rondom die artikulasie van fisiese pyn die pad ooplaat vir ernstige politieke en persepsuele komplikasies. Sy skryf: "The failure to express pain... will always work to allow its appropriation and conflation with debased forms of power; conversely, the successful expression of pain will always work to expose and make impossible that appropriation and conflation". Dit het duidelik geword uit die voorgaande dat die non-artikuleerbaarheid van pyn in die vroeë Christendom polities vir propaganda doeleindes na meerdere kante toe gebruik is. Hoewel dit verstaanbaar geword het binne die waarde generende kontekste van die vroeg-Christelike situasie, hoef daar geen goedkeurende woord daaroor gespreek te word nie. Dat daar in kontemporêre diskoerse en praktyke dikwels met verlange en bewondering geïdentifiseer word met die martelaarsdiskoerse van die antieke wêreld, beteken gewoon dat die werklikheid van die fisiese pyn wat hierdie mense ondergaan het, hulle weer eens ontneem word en hulle liggame weer eens as strategieë vir die verkryging van mag misbruik word.

\section{Literatuurverwysings}

Balasundaram, F J 1993. Martyrdom in the history of Christianity. Bangalore Theological Forum 25(2-3), 18-36.

Barton, C A 1989. The scandal of the arena. Representations 27, 1-36.

-, 1994. Savage miracles: The redemption of lost honor in Roman society and the sacrament of the gladiator and martyr. Representations 45, 42-71.

Bauman, R A 1967. The crimen maiestatis in the Roman Republic and Augustan Principate. Johannesburg: Witwatersrand University Press.

Bisbee, G A 1988. Pre-Decian acts of martyrs and commentarii. Philadelphia: Fortress Press.

Bowersock, G W 1995. Martyrdom and Rome. Cambridge: Cambridge University Press.

Fernando, L 1998. Martyrdom in the Christian tradition. Vidyayoti Journal of Theological Reflection 62(1), 11-21.

Figura, M 1996. Martyrdom and the following of Jesus. Communio 23(1), 101-109.

Coleman, K M 1990. Fatal charades: Roman executions staged as mythological enactments. The Journal of Roman Studies 80, 44-73.

Elsner, J 1996. Inventing imperium: texts and the propaganda of monuments in Augustan Rome, in Elsner, $\mathrm{J}$ (ed), Art and text in Roman culture, 32-54. Cambridge: Cambridge University Press.

Fischler, S 1998. Imperial cult: engendering the cosmos, in Foxhall, L \& Salmon, J (eds), When men were men: Masculinity, power and identity in classical antiquity, 165-183. London \& New York: Routledge.

Foucault, M 1979. Discipline and punish: The birth of the prison. London: Penguin Books. 
-, 1988. Technologies of the self, in Martin, Gutman \& Hutton (eds), Technologies of the self, 16-49.

Gustafson, W M 1997. Inscripta in fronte: Penal tatooing in late Antiquity. Classical Antiquity 16(1), 79-105.

Jones, A H M 1970. Augustus. London: Chatto \& Windus.

Manson, T W 1957. Martyrs and Martyrdom. Bulletin John Rylands Library 39, 463-484.

Martin, L H, Gutman, H \& Hutton, P H (eds) 1988. Technologies of the self: A seminar with Michel Foucault. Amherst: The University of Massachusetts Press.

Martyrdom of Polycarp, The apostolic fathers, vol 2. Loeb Classical Library. London: William Heinemann.

Martyrdom of Perpetua and Felicitas, Introduction, texts and translations by Herbert Musurillo. Pages106-131 in The Acts of the Christian Martyrs. Oxford: Clarendon Press.

Martyrs of Lyons, Introduction, texts and translations by Herbert Musurillo. Pages 62-85 in The Acts of the Christian Martyrs. Oxford: Clarendon Press.

Michie, H 1992. The greatest story (N) Ever told: The spectacle of recantation, in Mascia-Lees, F E \& Sharpe, P (reds). Tattoo, torture, mutiliation, and adornment: The denaturalization of the body in culture and text, 10-29. New York: State University of New York Press.

Musurillo, $\mathrm{H}$ 1972. The acts for the Christian martyrs. Oxford: Oxford University Press.

Perelman, C \& Olbrechts-Tyteca, L 1969. The new rhetoric: A treatise on argumentation. Notre Dame: Notre Dame.

Plinius, Epistle 10. Vertaal deur Betty Radice. Bladsye 293-295 in The letters of the younger Pliny. Vertaling en inleiding deur B Radice. London: Penguin Books.

Scarry, E 1985. The body in pain: The making and unmaking of the world. Oxford: Oxford University Press.

Shaw, B D 1993. The passion of Perpetua. Past \& Present 139, 3-45.

-, 1996. Body/power/identity: Passions of the martyrs. Journal of early Christian Studies 4, 269-312.

Tajra, H W 1994. The martyrdom of St. Paul Tübingen: J C B Mohr (Paul Siebeck).

Tertullian, Ad martyras. Translated by Alexander Roberts \& James Donaldson. Pages 1-7 in The writings of Tertullianus. Edited by A Roberts \& J Donaldson. Ante-Nicene Christian Library 11. Edinburgh: T \& T Clark.

Tertullian, De Spectaculis. Translated by Alexander Roberts \& James Donaldson. Pages 8-357 in The writings of Tertullianus. Edited by A Roberts \& J Donaldson. Ante-Nicene Christian Library 11. Edinburgh: T \& T Clark.

Vierow, H 1999. Feminine and masculine voices in the Passion of Saints Perpetua and Felicitas. Latomus 58(3), 600-619. 